\title{
The compromised airway: recognition and management
}

\begin{abstract}
Although failed intubation occurs rarely, complicated airway problems are common in anaesthetic practice. Usually, the sources of difficulty are obvious, for example facial trauma or congenital anomalies; occasionally, difficulties arise after induction of anaesthesia. The purpose of this discussion is to answer two key questions: What are the currently available methods of preoperative airway assessment? What are the more recently developed techniques to aid management of difficult airway problems? Since difficult paediatric airway problems were discussed at this symposium in 1989 , the focus is on the management of adult patients.
\end{abstract}

\section{Importance of the problem}

In a retrospective study, Samsoon found that failed tracheal intubation occurred with an incidence of 1:2230 cases. ' While newer techniques may have lessened this incidence, the potential exists for several failed intubations per year in a large hospital. Approximately one third of adverse outcomes (522 out of 1541) identified by the American Society of Anesthesiologists' Closed Claim Study were associated with respiratory events. ${ }^{2}$ Difficult tracheal intubation accounted for 87 of these cases with a median payment of $\$ 76,000$. Despite techniques such as fibreoptic intubation, difficult or failed intubation continues to be a persistent and costly problem.

\section{Airway assessment \\ Numerous authors have described methods of preoperative airway assessment. ${ }^{3-6}$ These range from simple bedside techniques to sophisticated radiological evaluations, and have been reviewed.' Once evaluation is complete, the findings need to be documented accurately and concisely. Until recently, organized programs to evaluate patients with difficult airway problems did not exist; however, the Difficult Airway Clinic of the University of Michigan allows such patients to be evaluated systematically with a variety of modalities, including fluoroscopy. ${ }^{9}$}

\section{Bedside techniques}

One of the most widely employed methods of airway evaluation is that of Mallampati. ${ }^{10}$ In this system, the principle observation is the visibility of the faucial pillars and uvula when the patient is seated and has the tongue

\section{C.J. Eagle MD FRCPC}

fully protruded with the mouth opened maximally. Based on this observation, patients can be divided into three classes (Table I). Mallampati found good correlation between this classification and difficulty in visualization of the larynx following induction of anaesthesia. ${ }^{4}$ Despite widespread use of this classification, problems have been found with observer variability, false positives and false negatives, and failure to consider factors such as cervical spine mobility."

In a detailed assessment of 633 adult patients, Wilson was able to study 20 different patient factors and airway measurements. ${ }^{5}$ Comparing "normal" and "difficult" patients in a prospective study, only five factors were found to correlate with difficult intubation. A scoring system was also developed (Table II). Employment of this scoring system revealed difficulties with false positive predictions. For example, if Wilson's risk-sum scoring system was adapted to pick up $75 \%$ of difficult airways prospectively (total score greater than or equal to 2 ), there was a false positive rate of $12.1 \%$.

Mallampati's classification, Wilson's risk-sum scoring system, and the difficulty of laryngoscopy at intubation have been assessed prospectively in 675 patients. ${ }^{12}$ The authors were unable to predict more than $50 \%$ of difficult laryngoscopies using either system. In addition, a high false positive rate was noted. For example, using Wilson's risk-sum a positive predictive value of $8.9 \%$ was measured. In other words, only $8.9 \%$ of patients predicted to be difficult actually proved to be difficult. Mallampati's system achieved a predictive value of only $4.4 \%$. The authors stated that they preferred the Wilson risk-sum assessment because of lower inter-observer variability.

Other assessment systems have been described. For example, Bellhouse described a system based on radiographic assessment of 19 patients whose tracheas had been difficult to intubate (Figure 1). This system, while easy to perform, has not been widely employed, subjected to formal evaluation, or compared with other methods. ${ }^{13}$

The problem of false positive identification of difficult laryngoscopy seems inherent to the design of simple airway evaluation systems. The inability to identify

From the Department of Anaesthesia, Foothills Hospital, Calgary, Alberta. 
TABLE I Mallampati's classification

Class 1 - Faucial pillars, soft palate and uvula could be visualized. Class 2 - Faucial pillars and soft palate could be visualized, but was masked by base of the tongue.

Class 3 - Only soft palate could be visualized.

(Reproduced from reference 4).

TABLE II Airway scoring system

\begin{tabular}{lll}
\hline Risk factor & \multicolumn{2}{l}{ Level } \\
\hline Weight & 0 & $<90 \mathrm{~kg}$ \\
& 1 & $90-110 \mathrm{~kg}$ \\
& 2 & $>110 \mathrm{~kg}$ \\
Head and neck movement & 0 & Above $90^{\circ}$ \\
& 1 & About $90^{\circ}$ (i.e. $\pm 10^{\circ}$ ) \\
Jaw movement & 2 & Below $90^{\circ}$ \\
& 0 & IG $>=5 \mathrm{~cm}$ or SLux $>0$ \\
Receding mandible & 1 & IG $<5 \mathrm{~cm}$ and SLux $=1$ \\
& 2 & IG $<5 \mathrm{~cm}$ SLux $<0$ \\
Buck teeth & 0 & Normal \\
& 1 & Moderate \\
& 2 & Severe \\
& 0 & Normal \\
& 1 & Moderate \\
\hline
\end{tabular}

SLux: Maximum forward protrusion of the lower incisors beyond upper incisors; IG: Incisor gap.

(Reproduced from reference 5).

reliably a patient with a difficult airway is a hindrance to the provision of safe anaesthetic care and accurate communication between anaesthetists.

\section{Flow-volume loops}

Of the currently available pulmonary function tests, flowvolume loops, which present gas flow rates and volumes graphically, allow the easiest recognition of airway obstruction. The shape of the loop may be helpful in identifying the site and nature of the obstruction (Figure 2). Normally, obstructions can be identified as either fixed or variable, intrathoracic or extrathoracic. In addition, obstructive defects may be differentiated from restrictive lesions. Nevertheless, there are limitations in the generation and interpretation of flow-volume loops. Patient cooperation is required to produce an accurate tracing. When upper airway obstruction coexists with lower airways disease, such as chronic bronchitis or in emphysema, the characteristic shape of the flow-volume loop may be obscured. ${ }^{14}$

\section{Radiological evaluation}

Patients with malignancies of the upper airway frequently

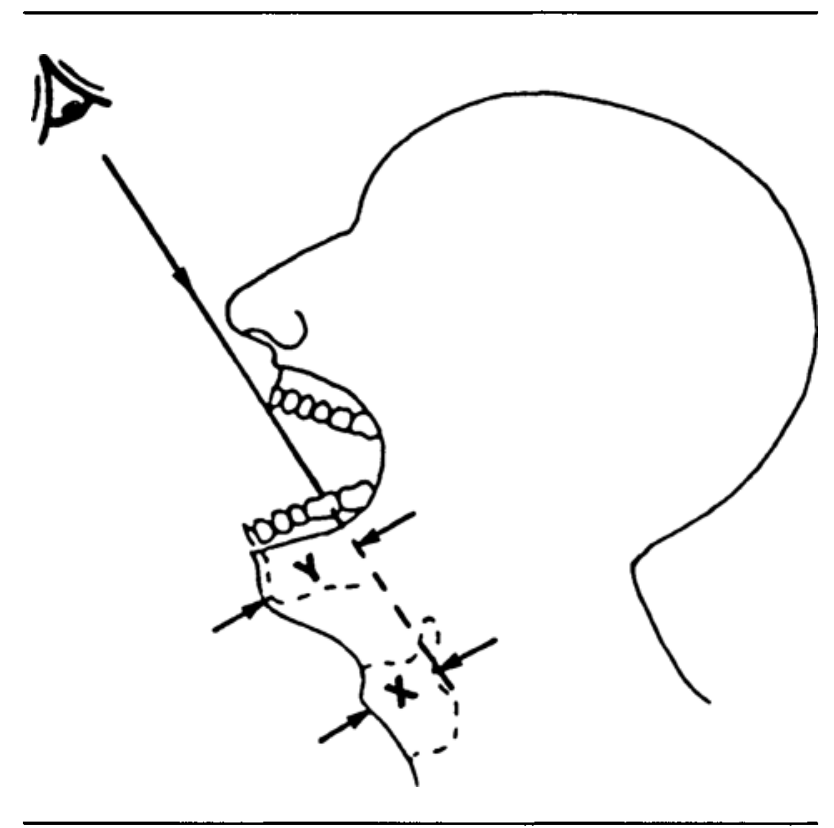

FIGURE 1 The line of vision (LOV) is a line drawn from the upper incisors to a point $1.5 \mathrm{~cm}$ posterior to the thyroid cartilage $(X)$. If distance $Y$ is small (less than $2.5 \mathrm{~cm}$ ), then there is little space for the tongue and laryngeal visualization will be difficult (from Bellhouse and Dore). ${ }^{13}$

\section{Flow-Volume Loop}

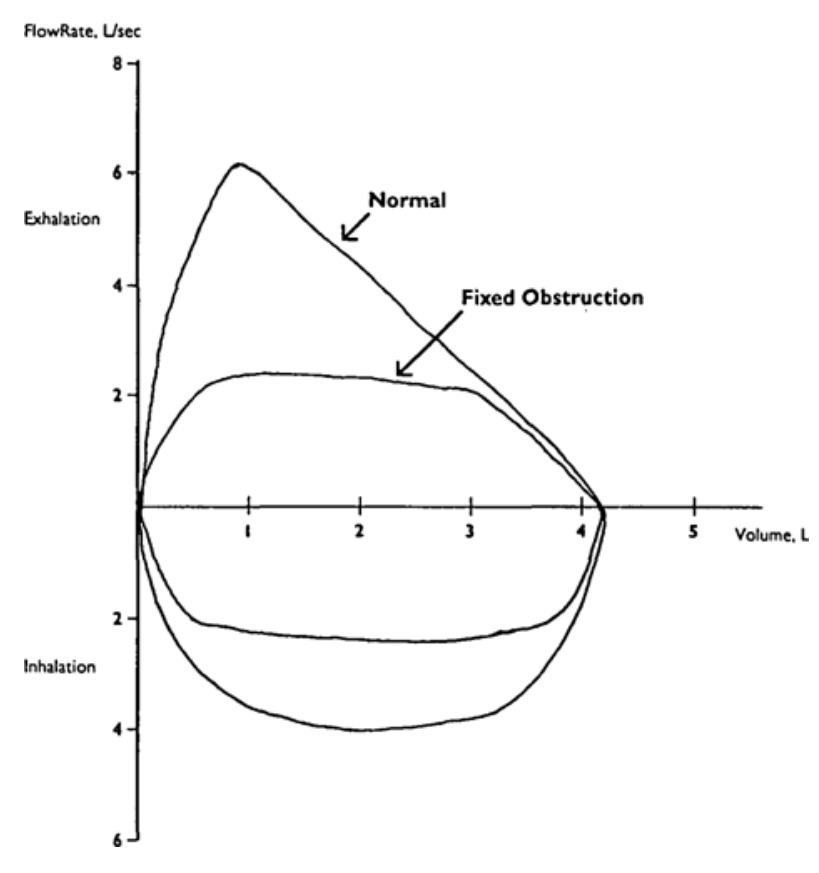

FIGURE 2 Normal and abnormal flow-volume loops. 


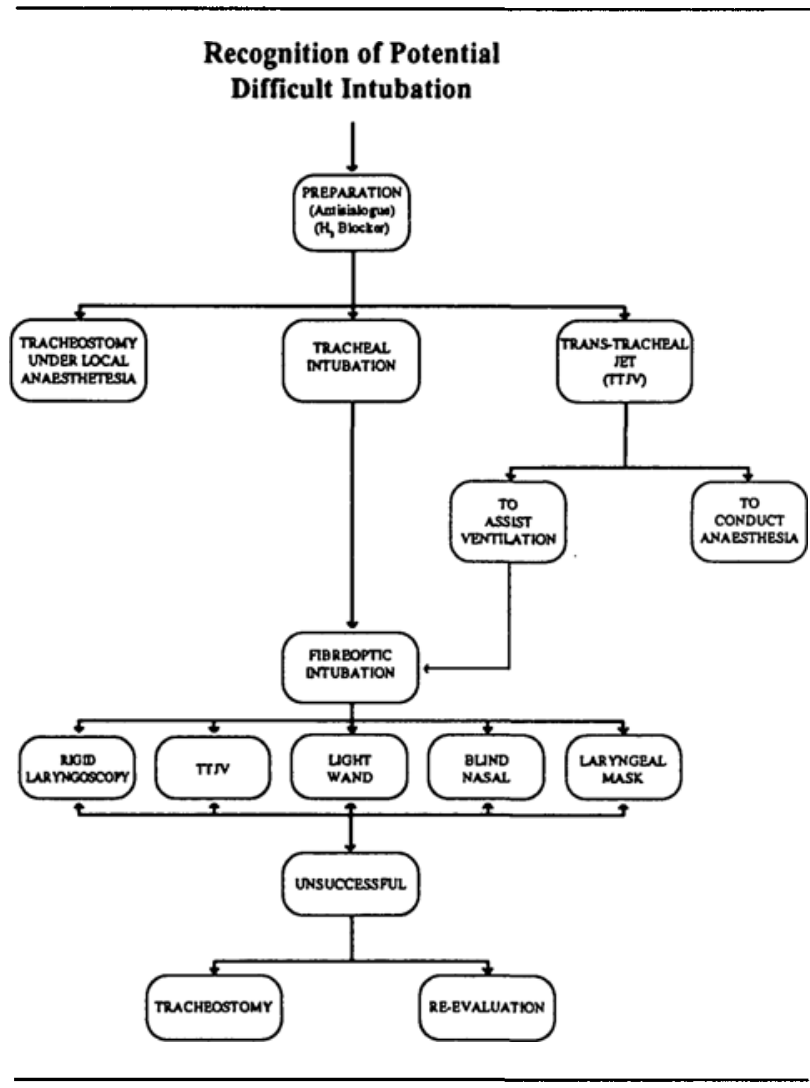

FIGURE 3 Management of anticipated difficult intubation. (Modified from: Ovassapian A. Fiberoptic Airway Endoscopy in Anesthesia and Critical Care. New York: Rover Press, 1990: 143.)

have CT or MRI scans performed as part of their preoperative workup. Both CT and MRI scans can give excellent axial views of laryngeal and subglottic tumours, but MRI also provides saggital and coronal views, which are potentially of greater value to the anaesthetist. More traditional investigations, such as lateral view roentgenograms of the soft tissues of the neck, cervical spine films, and routine chest roentgenograms, can provide useful information about the upper airway and surrounding structures.

Bellhouse studied lateral views of the neck (both with the head erect and mouth closed, and with the head fully extended and mouth fully open) in 18 patients with known difficult tracheal intubation and compared them with 14 "normals." It was found that reduced atlanto-occipital extension, reduced mandibular space, and increased antero-posterior thickness of the tongue were associated with difficult intubation. ${ }^{13} \mathrm{C}$-arm fluoroscopy has been used by the Difficult Airway Clinic of the University of Michigan to allow direct evaluation of cervical spine mobility and temporomandibular joint motion. ${ }^{9}$

\section{Techniques of management}

In this section, newer methods of management of the dif-

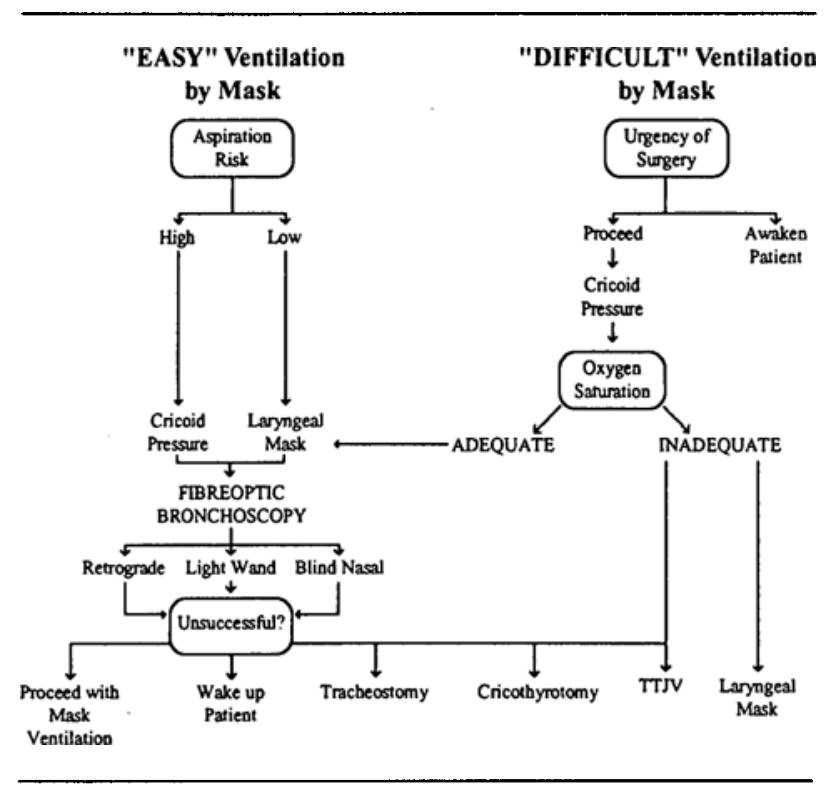

FIGURE 4 Management of unanticipated difficult intubation. (Modified from: Ovassapian A. Fiberoptic Airway Endoscopy in Anesthesia and Critical Care. New York: Rover Press, 1990: 144.)

ficult airway will be reviewed. Although not discussed, conservative techniques, for example, simple repositioning of the patient's head, use of a different type or size of laryngoscope blade, or blind nasal intubation, can also be successful in particular situations. When a difficult airway problem is encountered, the methods chosen will depend on the skill of the anaesthetist, the equipment available, and the urgency of the situation. Management options for both anticipated and unanticipated airway problems are outlined in Figures 3 and 4. It should be understood that these flow charts represent the author's opinion and have not been validated by clinical trials. Moreover, it is difficult to fault the shibboleth which states: patients with difficult airway problems should be dealt with awake, while maintaining spontaneous ventilation.

\section{Fibreoptic bronchoscopy}

Fibreoptic bronchoscopy has become the cornerstone of management of patients with both supra- and infraglottic pathology. Methods of performing and teaching fibreoptic tracheal intubation have been reviewed in detail. ${ }^{15-17}$ Newer techniques which improve the speed and success rate of fibreoptic intubation include: specially designed airways, retrograde techniques, and alternatives for oxygenation and ventilation during the performance of intubation. $^{18-21}$

Modification of the design of the Guedel airway has produced several devices which serve to protect the fibreoptic endoscope from biting or pressure injury and aid the endoscopist by serving as a rigid guide to maintain 
midline position. The airway described by Ovassapian has the advantage of being easily removable following intubation. The airway intubator developed by Williams can be used for guided blind oral intubation in addition to fibreoptic bronchoscopy. ${ }^{18}$

If the patient has been anaesthetised, use of these airways requires the anaesthetist to provide oxygen by mask ventilation prior to intubation. Intubation may be slowed because of the need for intermittent ventilation or hampered by the presence of an assistant at the head of the bed. In selected cases, an alternative approach may be appropriate. Anaesthesia may be induced following establishment of transtracheal high-frequency jet ventilation (TTJV) prior to tracheal intubation. As reported by Boucek, TTJV was established by a 14-gauge transtracheal catheter in four cases, following which anaesthesia was induced and uneventful fibreoptic intubation was accomplished. ${ }^{21}$ The advantages of this technique include unobstructed access to the mouth, reduced risk of aspiration and gastric distention, and a clear marker in the trachea to aid the endoscopist.

A less complicated adjunct to fibreoptic intubation involves retrograde passage of a long transtracheal wire $(150 \mathrm{~cm})$ through the mouth. This guidewire is placed through the biopsy port of the bronchoscope and can be used to direct the fibreoptic bronchoscope. This technique may be useful when routine fibreoptic bronchoscopy is difficult, for example in situations of trauma, haemorrhage, or deformity.

When difficulties are encountered, simple mechanical manoeuvres may also aid fibreoptic intubation. Anterior displacement of the tongue by forceps or a Magill laryngoscope blade can help to reveal an anteriorly placed larynx or lift a large floppy epiglottis. Insufflation of oxygen via the suction port may improve arterial oxygen tension and distend laryngeal structures resulting in improved visibility.

\section{The laryngeal mask}

First described in 1983, the laryngeal mask allows many of the complications of tracheal intubation to be avoided. ${ }^{22}$ It has been used for several purposes including definitive airway management for elective surgery, airway control in cases of both anticipated and unanticipated difficult intubation, as an adjunct to the investigation of tracheal tumours and stridor, and as an aid to the placement of bronchoscopes or endotracheal bougies. ${ }^{23-26}$ The major limitations to use of the laryngeal mask in non-life threatening situations are a failure rate of approximately $4 \%$, limitation of positive pressure ventilation to approximately $2 \mathrm{kPa}$, and failure to protect fully the lower airway from gastric material. ${ }^{27}$ Although a prospective study has shown that the laryngeal mask may seal the airway from leakage of dye, there are several case reports of pulmonary aspiration of gastric contents following its use. ${ }^{28.29}$ Despite these reports, it has been used successfully for Caesarean section following failure to achieve endotracheal intubation. ${ }^{30}$ The numerous case reports describing effective use of the laryngeal mask in difficult airway problems suggest that it can be a lifesaving tool, as well as serving as a bridge to tracheal intubation.

\section{Lighted stylets}

Although illuminated stylets have been available for many years, they continue to attract attention. ${ }^{31}$ Tracheal intubation is aided by transillumination of the larynx and trachea, an effect easily seen in a darkened operating room. A recent study of the use of one of these devices reported a failure rate of $2.1 \%$ in routine practice. ${ }^{32}$ Using another device, an illuminated stylet allowed faster tracheal intubation in awake patients than blind nasal intubation. ${ }^{33}$ Similar results have been reported when comparing oral intubation with the use of an illuminated stylet. ${ }^{34}$ In experienced hands, these devices can be used to achieve an excellent success rate in either awake or anaesthetized patients. It should be noted that comparative studies of illuminated stylets with other techniques such as fibreoptic intubation have not been performed.

\section{Retrograde intubation}

Retrograde intubation is a technique that has been available for over $30 \mathrm{yr}$, and continues to attract interest. ${ }^{35}$ The technique usually involves retrograde passage of a wire or epidural catheter via a needle placed through the cricothyroid membrane. Once delivered through the nose or mouth, the wire can be used as a guiding stylet for an endotracheal tube or tube changer, or as a guide for a fibreoptic bronchoscope. ${ }^{36}$ Although there is a risk of damage to mucous membranes, cartilage, posterior perforation into the oesophagus or damage to cricothyroid arteries, the risk appears to be low since few complications have been reported (but is not specifically known). One of the more frequently encountered difficulties with this technique is an inability to pass the tracheal tube beyond the larynx. This may be averted by use of the fibreoptic endoscope, or of an Eschmann stylet, or by tying the epidural catheter around the Murphy eye with a sliding knot and pulling the catheter and tube down into the larynx from the cricothyroid end of the catheter. ${ }^{37,38} \mathrm{~A}$ training program has been described using patients presenting for elective laryngectomy. ${ }^{39}$

Although most techniques for retrograde intubation involve puncture of the cricothryroid membrane, several potential advantages of using a cricotracheal approach have been identified by Abou-Madi. ${ }^{37}$ When the trachea is entered following a midline approach between the cricoid 
cartilage and first tracheal ring, the penetrating needle does not enter the cavity of the larynx and the cricothyroid arteries are avoided. This level is usually sufficiently caudad to avoid the thyroid isthmus. Intubation is facilitated by lower insertion of the guidewire into the trachea since the tube is placed beyond the vocal cords before the catheter or wire must be removed.

\section{Transtracheal jet ventilation (TTJV)}

The indications, methods of performing, and merits of various TTJV systems have been reviewed in detail. ${ }^{40}$ Transtrachial jet ventilation provides oxygen by two mechanisms: first, bulk flow of oxygen through the percutaneous cannula; and second, entrainment of air from the upper airway by the Venturi effect. As described by Benumof, TTJV has two principle indications: "to facilitate operations involving the airway," and to permit safe intubation of the trachea by fibreoptic or retrograde intubation, while preventing the cannot "intubate-ventilate" situation.

Benumof describes five systems of administering TTJV. The three best systems are: "jet injector powered by regulated wall or oxygen tank pressure, jet injection powered by unregulated pressure"; and use of the anaesthetic machine's flush system with non-compliant delivery tubing. Considerably less effective systems, which might nevertheless be lifesaving, are the use of the circle system (with the reservoir bag attached), and direct connection of the catheter to a self-inflating reservoir bag for manual ventilation.

Complications of TTJV have been reported, and may be divided into four categories: barotrauma, trauma due to catheter placement, migration of the catheter, and the effects of dry gases. ${ }^{41-43}$ Barotrauma is clearly a considerable concern with the use of high-pressure oxygen and a potential resistance to the exhalation of gas (noted to occur in $14.3 \%$ of patients in one series). ${ }^{44}$ Reported barotrauma has included subcutaneous and mediastinal emphysema, and pneumothorax. It is more common following nonelective attempts to control the airway. ${ }^{41}$

\section{The jet stylet catheter}

While TTJV can aid the management of the difficult airway, placement of a percutaneous tracheal catheter may traumatize tissues and migration of the catheter may lead to barotrauma. In some situations, a device called the jet stylet catheter may minimize these risks..$^{45}$ The jet stylet is a $65-\mathrm{cm}$ hollow polyethylene tube available with three different internal diameters. The tube may be connected to either an anaesthetic system by means of a $15-\mathrm{mm}$ endotracheal tube adapter or to a jet injector by a metal female Luer lock cone adapter.

The jet stylet is placed orally by direct laryngoscopy, rigid bronchoscopy, retrograde technique, or through a preexisting endotracheal tube. Once inserted the lungs can be ventilated by any of the available jet systems. ${ }^{46}$ This device is a useful adjunct to the extubation of patients with upper airway pathology or recent surgery. Assuming weaning variables are met, a jet stylet catheter is placed through the endotracheal tube prior to extubation and the tube is then removed. If the patient requires reintubation, the jet stylet can be used to provide temporary ventilation and also to serve as a stent for endotracheal tube replacement which avoids a "trial by fire" approach to extubation.

\section{Cricothyrotomy}

A variety of cricothyrotomy instruments is currently marketed. They may be divided into two classes: those which allow egress of exhaled gas through the lumen; and those with small lumens requiring a patent larynx for exhalation and suctioning. Examples of the first include the NuTrake $^{\circledR}$ (International Medical Devices, Northridge, CA) and the Melker Emergency Cricothyrotomy Catheter Set ${ }^{\circledR}$ (Cook Critical Care, Stouffville, Ontario). The TransCricothyrotomy Device ${ }^{\circledR}$ (VBM Medizintechnik, Sulz/Neckar, Germany), a 13-gauge plastic connector with a fixation attachment, is an example of the second type. The second type of cannula is most useful for jet ventilation (see above). When the Nu-Trake device was used in dogs, several complications were noted including submucosal haematomas and cricoid cartilage injury. In addition, first-time operators were noted to have difficulty placing the device. ${ }^{47}$ Despite the availability of these and other devices, an informal survey of anaesthetists practicing in a teaching hospital revealed that only a minority had any clinical experience of cricothyrotomy.*

\section{Newer laryngoscope blade designs}

The design of the laryngoscope can be crucial in addressing specific airway problems. McIntyre reviewed the anatomical variations associated with difficult intubation (prominent sternal region, small interincisor distance, small mouth, and anterior larynx) and identified the key features of laryngoscope design for each type of problem. ${ }^{48}$ New laryngoscope designs continue to appear which offer advantages in specific circumstances. One such example was described by Bellhouse ${ }^{49}$ of a laryngoscope with a straight blade bent to $45^{\circ}$ at the midpoint. The lamp is two centimeters from the tip and a prism may be attached for extremely difficult situations (very prominent upper incisor teeth or very anterior larynx). Bellhouse reported excellent success with its use in over 3500 intubations, but no comparative trials were performed.

\footnotetext{
* Eagle $C J$ (unpublished) Survey of anaesthetists at Foothills Hospital, Calgary, 1991.
} 


\section{Conclusion}

Unanticipated difficulties continue to occur in airway management. While newer systems of evaluation show some promise, the problem of poor predictive value limits their usefulness. Newer radiological techniques are useful for the assessment of patients with known pathology or anatomical difficulty but are of little help when unexpected problems arise. Several new tools are available which aid management of both anticipated and unanticipated airway problems. The anaesthetist should have a clear "fall back" plan of which of these techniques to use in emergency or urgent situations. Published algorithms may aid in the selection of appropriate techniques, but the anaesthetist must also develop dexterity with the particular technique chosen.

\section{References}

1 Samson GLT, Young JRB. Difficult tracheal intubation: a retrospective study. Anaesthesia 1987; 42: 487-90.

2 Caplan RP, Posner KL, Wand RJ, Cheney FW. Adverse respiratory events in anesthesia: a closed claims analysis. Anesthesiology 1990; 72: 828-33.

3 MacIntyre JWR. The difficult tracheal intubation. Can J Anaesth 1987; 34: 204-13.

4 Mallampati $S R$, Gatt SP, Gugino $L D$. A clinical sign to predict difficult tracheal intubation: a prospective study. Can Anaesth Soc J 1985; 32: 429-34.

5 Wilson ME, Spiegelhalter D, Robertson JA, Lesser $P$. Predicting difficult intubation. Br J Anaesth 1988; 61: 211-6.

6 Cass NM, James NR, Lines V. Difficult direct laryngoscopy complicating intubation for anaesthesia. BMJ 1956; 1: 488-51.

7 Capan LM. Airway management. In: Capan LM, Miller SM, Turndorf H (Eds.). Trauma: Anaesthesia and Intensive care. Philadelphia: JB Lippincott Company, 1991; 43-82.

8 Davies JM, Eagle CJ. M.O.U.T.H.S. (letter). Can J Anaesth 1991; 38: 687-8.

9 Norton $M L$, Brown $A C D$. Difficult airway clinic. In: Norton ML, Brown ACD (Eds.). Atlas of the Difficult Airway. St. Louis: Mosby-Year Book, Inc., 1991; 33-42.

10 Mallampati SR: Clinical sign to predict difficult tracheal intubation (hypothesis) (letter). Can Anaesth Soc J 1983; 30: 316-7.

11 Wilson ME, John R. Problems with the Mallampati sign. Anaesthesia 1990; 456: 486-502.

12 Oates JDL, Macleod AD, Oates PD, Pearsall FJ, Howie $J C$, Murray $G D$. Comparison of two methods for predicting difficult intubation. Br J Anaesth 1991; 66: 305-9.

13 Bellhouse $C P$, Dore $C$. Criteria for estimating likelihood of difficulty of endotracheal intubation with the Macintosh laryngoscope. Anaesth Intensive Care 1988; 16: 329-37.
14 Gelb AF, Tashkin DP, Epstein JD, et al. ND-YAG laser surgery for severe tracheal stenosis physiologically and clinically masked by severe diffuse obstructive pulmonary disease. Chest 1987; 91: 166-70.

15 Roberts $J T$ (Ed.). Fiberoptics in anesthesia. Anesthesiology Clinics of North America 1991; 9: 1-193.

16 Roberts JT. Preparing to use the flexible fiberoptic laryngoscope. Journal of Clinical Anesthesia 1991; 3: 64-75.

17 Ovassapian A. Fiberoptic airway endoscopy in anesthesia and critical care. New York: Raven Press, 1990.

18 Williams $R T$, Maltby $J R$. Airway intubator. Anesth Analg 1982; 61: 309.

19 Ovassapian A. A new fiberoptic intubating airway. Anesth Analg 1987; 66: S132.

20 Lechman MJ, Donahoo JS, MacVauch H(III). Endotracheal intubation using percutaneous retrograde guide wire insertion followed by antegrade fiberoptic bronchoscopy. Crit Care Med 1986; 14: 589-90.

21 Boucek CD, Gunnerson HB, Tullock WC. Percutaneous transtracheal high-frequency jet ventilation as an aid to fiberoptic intubation. Anesthesiology 1987; 67: 247-9.

22 Brain $A I J$. The laryngeal mask: a new concept in airway management. Br J Anesth 1983; 55: 801-5.

23 Brain AI, McGhee TD, McAteer EJ, Thomas A, Abu-Saad $M A, B o s h m a n J A$. The laryngeal mask airway. Development and preliminary trials of a new type of airway. Anaesthesia 1985; 40: 356-61.

24 Brain AJ. Three cases of difficult intubation overcome by the laryngeal mask airway. Anaesthesia 1985; 40: 353-5.

25 McNamee CJ, Meyers B, Pagliero KM. Flexible bronchoscopy via the laryngeal mask: a new technique. Thorax 1991; 46: 141-2.

26 Allison A, McCrory J. Tracheal placement of a gum elastic bougie using the laryngeal mask airway. Anaesthesia 1990; 45: 419-20.

27 Maltby JR, Loken RG, Watson NC. The laryngeal mask airway: clinical appraisal in 250 patients. Can J Anaesth 1990; 37: 509-13.

28 John RE, Hill S, Hughes TJ. Airway protection by the laryngeal mask. A barrier to dye placed in the pharynx. Anaesthesia 1991: 46: 366-7.

29 Griffin $R M$, Hacher $J J$. Aspiration pneumonia and the largyngeal mask airway. Anaesthesia 1990; 45: 1039-40.

$30 \mathrm{McCrirrick} A$. The laryngeal mask airway for failed intubation at caesarian section. Anaesth Intensive Care 1991; 19: 135 .

31 MacIntosh R, Richards $H$. Illuminated introducer for endotracheal tubes. Anaesthesia 1957; 12: 223-5.

32 Graham $D H$, Doll WA, Robinson $A D$, Warriner $C B$. Intubation with lighted stylet (letter). Can J Anaesth 1991; 38: 261-2.

33 Fox DJ, Castro T, Rastrelli AJ. Comparison of intubation 
techniques in the awake patient: the Flexi-Lum ${ }^{8}$ surgical light (lightwand) versus blind nasal approach. Anesthesiology 1987; 66: 69-71.

34 Ellis DG, Jakymec A, Kaplan RM, et al. Guided orotracheal intubation in the operating room using a lighted stylet: comparison with direct laryngoscopic technique. Anesthesiology 1986; 64: 823-6.

35 Waters $D J$. Guided blind endotracheal intubation. Anaesthesia $1963 ; 18: 158$.

36 King HK, Wang LF, Khan AK, Wooten DJ. Translaryngeal guided intubation for difficult intubation. Crit Care Med 1987; 15: 869-71.

37 Abou-Madi $M N$, Trop $D$. Pulling versus guiding: a modification of retrograde guided intubation. Can J Anaesth 1989; 36: 336-9.

38 Freun $P R$, Rooke A, Schmid H. Retrograde intubation with a modified Eschmann stylet. Anesth Analg 1988; 67: 596-606.

39 Guggenberger $H$, Lenz $G$. Training in retrograde intubation (letter). Anesthesiology 1988; 69: 292.

40 Benumof JL, Scheller MS. The importance of transtracheal jet ventilation in the management of the difficult airway. Anesthesiology 1989; 71: 769-98.

41 Smith BR, Babinski M, Klain M, Pfaeffle H. Percutaneous transtracheal ventilation. J Am Coll Emerg Physicians 1976; 5: 765-70.

42 Monnier PH, Ravussin P, Savany M, Freeman $J$. Percutaneous transtracheal ventilation for laser endoscopic treatment of laryngeal and subglottic lesions. Clin Otolaryngol 1988; 13: 209-17.

43 Thomas $T$, Zornow $M$, Scheller MS, Unger R. The efficacy of these difficult modes of transtracheal ventilation in hypoxic hypercabic swine. Can J Anaesth 1988; 35: S61.

44 Oliverio $R$, Ruder CB, Fermon C, Curd A. Report on pneumothorax secondary to ball-value obstruction during jet ventilation. Anesthesiology 1979; 51: 255-6.

45 Bedger RC, Charg JL. A jet stylet endotracheal catheter for difficult airway management. Anesthesiology 1987; 66: 221-3.

46 Benumof JL, Gaughan S, Ozaki GT, Rask R. Connecting a jet stylet to a jet injector. Anesthesiology 1991; 74: 963-4.

47 Bjoraker $D G$, Kumar $N B$, Brown $A C D$. Evaluation of an emergency cricothyrotomy instrument. Crit Care Med 1987; 15: 157-60.

48 McIntyre JWR. Laryngoscope design and the difficult adult tracheal intubation. Can J Anaesth 1989; 36: 94-8.

49 Bellhouse $C P$. An angulated laryngoscope for routine and difficult tracheal intubation. Anesthesiology 1988; 69: 126-9. 


\section{C.J. Eagle MD}

Même si l'intubation manquée se produit rarement, les problèmes de voies aériennes difficiles sont courants en pratique anesthésique. Habituellement, les causes de difficultés sont évidentes, comme dans le trauma facial et anomalie congénitale. Occasionnellement les difficultés surviennent après l'induction de l'anesthésie. L'objectif de cette discussion est de répondre à deux questions principales: Quelles sont les méthodes courantes disponibles d'évaluation des voies aériennes? Quelles sont les techniques récentes développées pour faciliter le contrôle des voies aériennes difficiles? Puisque les voies aériennes difficiles chez les enfants ont fait l'objet d'une discussion à ce symposium en 1989 , nous mettrons l'accent sur la conduite à tenir chez les adultes.

\section{Importance du problème}

Dans une étude rétrospective, Samsoon a trouvé une incidence d'échecs à l'intubation trachéale de l'ordre de 1 : $2230 .^{1}$ Même si les techniques nouvelles peuvent avoir réduit cette incidence, il existe toujours un potentiel d'échec important chaque année, dans un hôpital majeur. A peu près $1 / 3$ des complications (522 sur 1541 ) mises à jour par l'étude des causes réglées de la Société Américaine des Anesthésistes ont été associées à un événement de type respiratoire. ${ }^{2} \mathrm{~L}$ 'intubation trachéale difficile était impliquée dans 87 de ces cas, avec un règlement monétaire median de $76000 \$$. En dépit des techniques telles que l'intubation à fibre optique, l'intubation difficile ou infructueuse continue à représenter un problème permanent et coûteux.

\section{Évaluation des voies aériennes}

De nombreux auteurs ont décrit des méthodes d'évaluation préopératoire des voies aériennes. ${ }^{3-6}$ Celles-ci incluent autant les techniques simples faites au chevet, que les évaluations radiologiques complexes, et elles ont été revues. ${ }^{7}$ Une fois l'évaluation complétée les trouvailles doivent être documentées de façon précise et concise. ${ }^{8}$ Jusqu'à récemment, des programmes organisés dans le but d'évaluer les patients avec les voies aériennes difficiles n'existent pas; cependant, la clinique de voies aériennes de l'Université du Michigan permet à de tels patients d'être évalués de façon systématique avec une variété de modalités incluant la fluoroscopie.

\section{Les voies aériennes à risque: dépistage et contrôle}

\section{Techniques de chevet}

Une des méthodes d'évaluation les plus courante est celle de Mallampati. ${ }^{10}$ Dans ce système, l'observation principale est la visibilité de la luette et des piliers du pharynx lorsque le patient est assis et a la langue complètement sortie, avec la bouche ouverte au maximum. Sur la base de cette observation, les patients peuvent être divisés en trois classes (voir la Tableau I). Mallampati a trouvé une bonne corrélation entre ces classifications et la difficulté de visualisation du larynx à la suite de l'induction de l'anesthésie. ${ }^{4}$ En dépit de l'utilisation importante de cette classification, on a relevé des problèmes de variabilité d'observateur, des faux positifs et faux négatifs, et l'oubli de considérer des facteurs telle la mobilité de la colonne cervicale."

Dans son étude détaillée de 633 patients adultes, Wilson a pu évaluer 20 « facteurs-patients » et mesures des voies aériennes différents. ${ }^{5}$ En comparant les patients normaux et difficiles dans une étude prospective, seulement cinq facteurs ont pu être associés significativement à l'intubation difficile. Il a aussi développé un système de cotes (voir Tableau II). L'utilisation de ce système de cotes a mis évidence des difficultés suite à la prédiction de faux positifs. Par exemple si le système de somme de points de Wilson était adapté pour recueillir $75 \%$ des intubations difficiles sur une base prospective (pointage total $\geq a ̀ 2$ ), on retrouve un taux de faux positif de 12,1\%.

La classification de Mallampati, le système de points de risque de Wilson et la difficulté à la laryngoscopie pendant l'intubation ont été revus prospectivement chez 675 patients. ${ }^{12}$ Les auteurs ont été incapables de prédire plus de $50 \%$ des laryngoscopies difficiles en utilisant l'un ou l'autre système. De plus, on note un taux élevé de faux positifs. Par exemple en utilisant le système de Wilson on retrouve une valeur prédictive positive de $8,9 \%$. En d'autres mots seulement $8,9 \%$ des patients chez lesquels on prédit une intubation difficile voient confirmer chez eux cette prédiction. Le système de Mallampati produit quant à lui une valeur prédictive positive de seulement $4,4 \%$. Les auteurs concluent qu'ils préfèrent le système de Wilson à cause d'une plus faible variabilité entre observateurs.

D'autres systèmes d'évaluation ont été décrits. Par exemple Bellhouse décrit un système basé sur l'évaluation radiologique de 19 patients difficiles à intuber (Figure 1). 


\section{TABLE I Classification de Mallampati}

Classe 1 - Piliers du palais, palais mou et luette visualisés

Classe 2 - Visualisation du palais mou et des piliers qui sont masqués par contre par la base de la langue

Classe 3 - Visualisation seulement du palais mou

(Reproduit à partir de la référence 4 ).

TABLE II Système de classification des voies aériennes

\begin{tabular}{lll}
\hline Facteurs de risque & \multicolumn{2}{l}{ Niveau } \\
\hline Poids & 0 & $<90 \mathrm{~kg}$ \\
& 1 & $90-110 \mathrm{~kg}$ \\
& 2 & $>110 \mathrm{~kg}$ \\
Mouvements de la tête et du cou & 0 & $>90^{\circ}$ \\
& 1 & $\approx 90^{\circ}$ (i.e. $\left.\pm 10^{\circ}\right)$ \\
Mouvements de la mâchoire & 2 & $<90^{\circ}$ \\
& 0 & e.i. $\geq 5 \mathrm{~cm}$ ou SLux $>0$ \\
& 1 & e.j. $<5 \mathrm{~cm}$ et SLux $=1$ \\
Mandibule en retrait & 2 & e.i. $<5 \mathrm{~cm} \mathrm{SLux} \leq 0$ \\
& 0 & Normal \\
Protrusion des incisives & 1 & Modéré \\
& 2 & Sévère \\
& 0 & Normal \\
& 1 & Modéré \\
& 2 & Sévère
\end{tabular}

SLux : protrusion par l'avant et maximals des incisives inférieures au-delà des incisives supérieures; EG : écart entre les incisives. (Reproduit à partir de la référence 5).

Ce système, même s'il est facile à utiliser n'a pas été largement employé, et il doit être soumis à une évaluation formelle ou comparé à d'autres méthodes. ${ }^{13}$ Le problème de la prédiction erronée d'une laryngoscopie difficile semble inhérent à la structure des systèmes simples d'évaluation. L'incapacité d'identifier de façon fiable un patient avec des voies aériennes difficiles constitue un obstacle à l'apport de soins anesthésiques sécuritaires et à la communication précise entre anesthésistes sur le sujet.

\section{Courbes débit volume}

Parmi les épreuves de fonction respiratoire actuellement disponibles, les courbes débit volume qui présentent les débits de gaz mis en relation avec les volumes, permettent une reconnaissance facile de l'obstruction respiratoire. La forme de la courbe peut être utile pour identifer le site et la nature de l'obstruction (Figure 2). Normalement, les obstructions peuvent être identifiées comme fixes ou variables, être thoraciques ou extra-thoraciques. De plus, les malformations obstructives peuvent être différenciées des lésions restrictives. Cependant il y a des limitations dans la génération et l'interprétation des courbes débit volume. La coopération des patients est requise pour

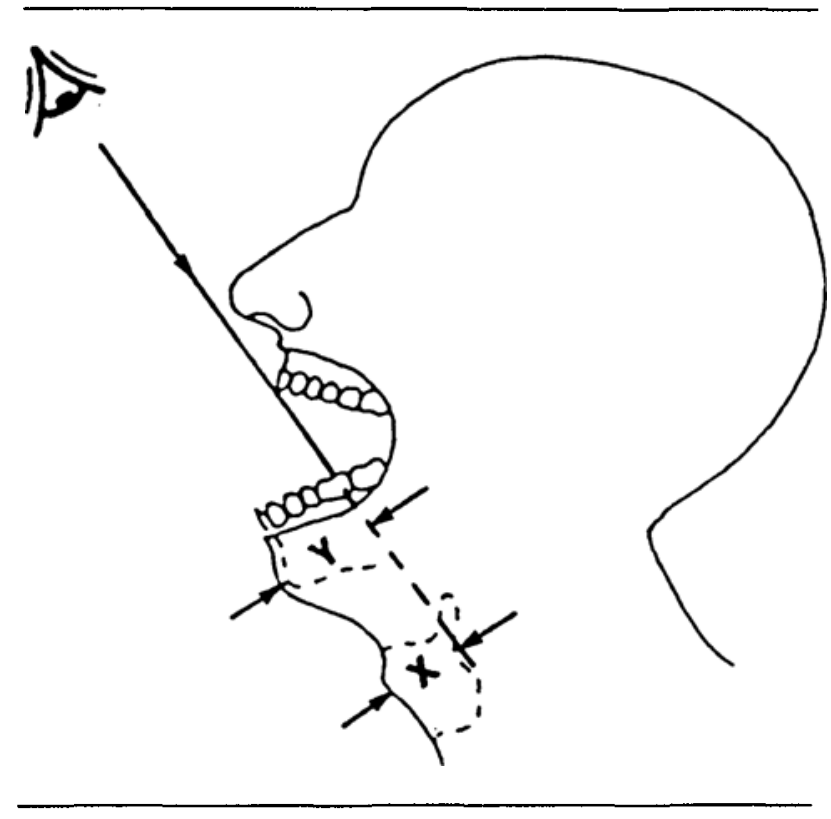

FIGURE 1 La ligne de vision (LOV) est une ligne tracée à partir des incisives supérieures à un point postérieur de $1,5 \mathrm{~cm}$ au cartilage thyroïde (X). Si la distance $Y$ est petite (moins de $2,5 \mathrm{~cm}$ ), dès lors il y a peu d'espace pour la langue et la visualisation du larynx sera difficile (de Bellhouse et Doré). ${ }^{13}$

produire un tracé précis. Lorsqu'une obstruction des voies aériennes supérieures coexiste avec une maladie des petites voies aériennes, comme dans la bronchite chronique ou l'emphysème, la forme caractéristique de la courbe de débit volume peut être floue. ${ }^{14}$

\section{Évaluation radiologique}

Des patients avec lésions malignes des voies aériennes supérieures ont souvent une tomographie axiale ou une résonance magnétique incluse dans leur évaluation préopératoire. Autant la tomographie axiale que la résonance magnétique donnent d'excellentes vues des lésions laryngées et subglottiques, mais la résonance magnétique ajoute aussi des vues sagittales et coronales, qui sont potentiellement de plus grande valeur pour l'anesthésiste. Des évaluations plus traditionnelles, comme les radiographies latérales des tissus mous du cou, et la radiographie pulmonaire de routine, peuvent fournir une information utile sur les voies aériennes supérieures et les structures environnantes.

Bellhouse a étudié les prises latérales du cou (autant avec la tête droite et la bouche fermée, qu'avec la tête en hyper-extension et la bouche complètement ouverte) chez 18 patients avec des difficultés connues d'intubation trachéale et les a comparées à celles de 14 patients dits normaux. Il a trouvé qu'une diminution de l'extension atlanto-occipitale, de l'espace mandibulaire, ainsi qu'un épaississement augmenté antéro-postérieur de la langue 


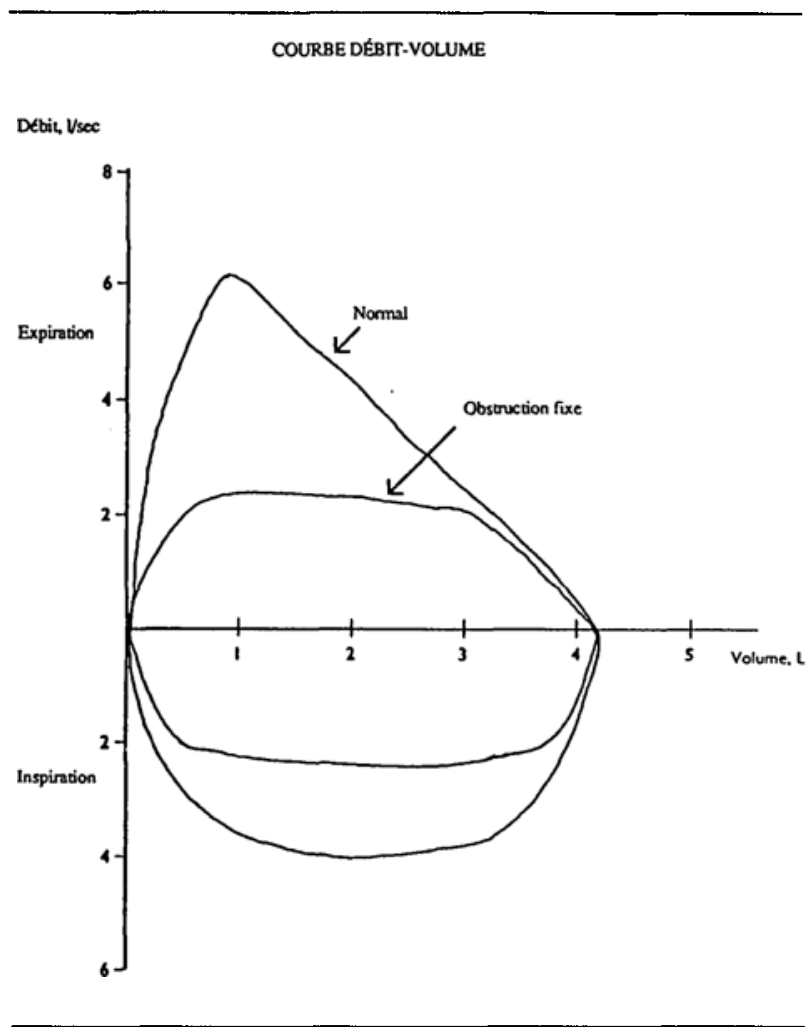

FIGURE 2 Courbe débit et volume normal et anormal.

sont associés à une intubation difficile. ${ }^{13}$ La fluoroscopie avec bras en $\mathrm{C}$ a été utilisée à la clinique des voies aériennes difficiles de l'Université du Michigan pour permettre une évaluation directe de la mobilité de la colonne cervicale et de l'articulation temporomandibulaire.

\section{Approches actuelles}

Nous allons revoir dans cette section les nouvelles approches des voies aériennes difficiles. Même si elles ne font pas l'objet de notre discussion, les techniques conservatrices, par exemple le repositionnement de la tête du patient, l'utilisation d'un type ou d'une taille différente de lame de laryngoscope, ou l'intubation nasale à l'aveugle, permettront aussi de se tirer d'une situation difficile. Lorsque confronté avec une voie aérienne difficile, les méthodes choisies dépendront de l'habileté de l'anesthésiste, de l'équipement disponible, et de l'urgence de la situation. Les choix de conduite pour les problèmes anticipés ou non sont résumés dans les Figures 3 et 4 . Il faut comprendre que ces algorithmes représentent l'opinion de l'auteur et n'ont pas été validés dans des essais cliniques. De plus, il est difficile de prendre en défaut l'adage qui dit: des patients avec un problème de voies aériennes difficiles devraient être maintenus éveillés, en ventilation spontanée.

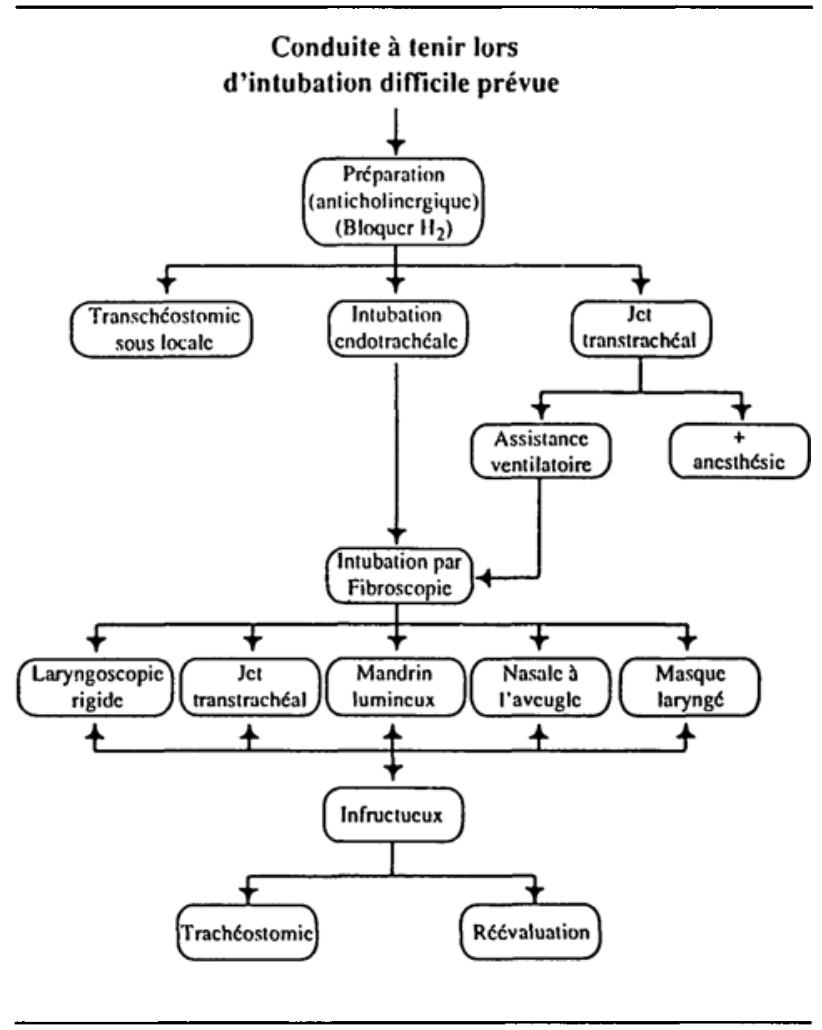

FIGURE 3 Conduite à tenir lors d'intubation difficile prévue. (Modified from : Ovassapian A. Fiberoptic Airway Endoscopy in Anesthesia and Critical Care. New York : Rover Press, 1990: 143.)

\section{Bronchoscopie par fibre optique}

La bronchoscopie par fibres optiques est devenue la pierre angulaire de la conduite à tenir chez les patients avec pathologie supra ou infraglottique. Les méthodes d'enseignement et d'exécution de l'intubation trachéale par fibres optiques ont été revues en détail. ${ }^{15-17}$ Les nouvelles techniques qui augmentent la vitesse et le taux de succès de l'intubation à fibres optiques comprennent : des pièces buccales spéciales, des techniques rétrogrades, et des alternatives pour l'oxygénation et la ventilation pendant l'intubation. ${ }^{18-21}$

La pièce buccale de Guedel a subi des modifications qui visent à protéger l'endoscope des morsures ou des bris par pression et aider l'endoscopiste qui va s'en servir comme guide rigide pour maintenir une position centrale. La pièce buccale d'Ovassapian a l'avantage d'être facilement retirée après l'intubation. «L'Airway Intubator» développé par Williams peut aussi être utilisé lors de l'intubation orale à l'aveugle au delà de son emploi pour la bronchoscopie à fibres optiques. ${ }^{18}$

Si le patient a été anesthésié, l'anesthésiste doit avant l'intubation le ventiler au masque avec de l'oxygène s'il veut utiliser ces pièces buccales. L'intubation peut demander plus de temps à cause du besoin intermittent de 


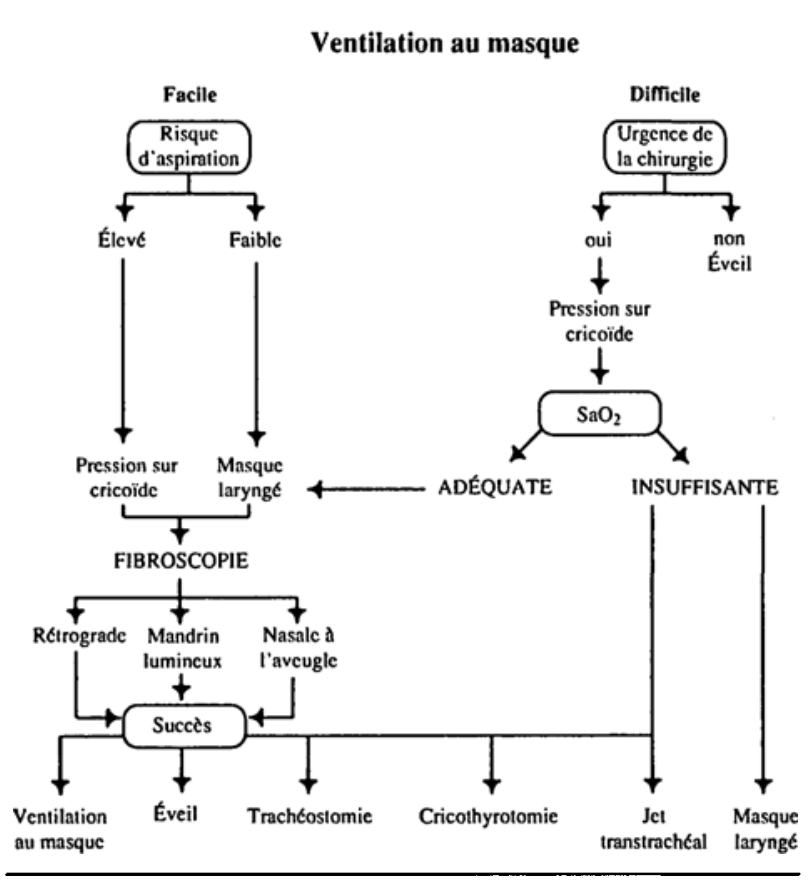

FIGURE 4 Intubation difficile inattendue. (Modified from: Ovassapian A. Fiberoptic Airway Endoscopy in Anesthesia and Critical Care. New York : Rover Press, 1990 : 144.)

ventilation ou encore être rendue plus difficile à cause de la présence d'un assistant à la tête du lit. Dans certains cas une alternative peut être utile : ainsi l'anesthésie peut être induite après la mise en marche d'une ventilation transtrachéale par jet à haute fréquence avant l'intubation trachéale. Tel que rapporté par Boucek, la ventilation trachéale à haute fréquence a été mise en fonction à l'aide d'un cathéter trans-trachéal de calibre 14 dans 4 cas, par la suite il y a eu induction de l'anesthésie et réalisation sans incident d'une intubation par fibroscope. ${ }^{21}$ Les avantages de cette technique comprennent un accès libre à la bouche, un risque diminué d'aspiration et de distension gastrique, et un repère bien défini dans la trachée pour aider l'endoscopiste.

Une manoeuvre accessoire moins compliquée pour l'intubation par fibroscope implique le passage rétrograde d'un long filin métallique $(150 \mathrm{~cm})$ par la bouche. Ce guide métallique est passé à travers l'orifice de biopsie du bronchoscope et peut être utilisé pour diriger celui-ci. Cette technique peut être utile lorsque la bronchoscopie habituelle par fibres optiques est difficile, par exemple dans les situations de traumatisme, d'hémorragie, ou de difformité.

Lorsque l'on rencontre des difficultés, de simples manoeuvres mécaniques peuvent aussi aider à l'intubation par fibroscope. Le déplacement antérieur de la langue par des pinces, ou une lame de laryngoscope de type Magill peuvent aider à mettre en évidence un larynx antérieur ou à soulever une épiglotte de grande dimension et molle. L'insufflation d'oxygène par l'orifice d'aspiration peut améliorer la tension artérielle en oxygène et distendre les structures laryngées, ce qui améliore la visibilité

\section{Le masque laryngé}

Décrit pour la première fois en 1983, le masque laryngé permet d'éviter plusieurs des complications de l'intubation. ${ }^{22}$ Il a été utilisé dans bien des situations qui comprennent le contrôle total des voies aériennes en chirurgie élective, leur contrôle lorsqu'il y a des difficultés anticipées ou non d'intubation difficile, comme auxiliaire lors de l'évaluation de tumeur trachéale et de stridor, et lors de la manipulation d'un bronchoscope ou de bougies endotrachéales. ${ }^{23-26}$ Les limites les plus importantes à l'utilisation d'un masque laryngé, dans les situations non menaçantes pour la vie, sont un taux d'échec d'environ $4 \%$, la limitation de la pression de ventilation positive à environ $2 \mathrm{kPa}$, et l'échec à protéger complètement les voies aériennes basses du contenu gastrique. ${ }^{27}$ Même si une étude prospective a démontré que le masque laryngé peut protéger complètement les voies aériennes de fuites de colorant, il y a quand même plusieurs cas rapportés d'aspiration de liquide gastrique dans les poumons à la suite de son utilisation. ${ }^{28,29}$ Malgré ces cas rapportés, il a été employé avec succès dans une césarienne après qu'il y ait eu échec à l'intubation endotrachéale. ${ }^{30}$ Les nombreux rapports de cas qui décrivent l'utilisation avec succès du masque laryngé dans des situations de voies aériennes difficiles suggèrent qu'il peut être un instrument de maintien de la vie, aussi bien qu'un intermédiaire à l' intubation trachéale.

\section{Les stylets lumineux}

Même si les stylets lumineux sont disponibles depuis plusieurs années ils continuent à attirer l'attention.. L'intubation trachéale est facilitée par la trans-illumination du larynx et de la trachée, un effet facilement vérifié dans une salle d'opération obscure. Une étude récente de l'utilisation d'un de ces instruments rapporte un taux d'échec de $2,1 \%$ en pratique courante. ${ }^{32}$ L'utilisation d'un stylet lumineux légèrement différent a permis une intubation trachéale plus rapide chez les patients éveillés que l'intubation nasale à l'aveugle ${ }^{33}$ Une comparaison de l'intubation orale et l'utilisation d'un stylet lumineux donne des résultats similaires. ${ }^{34}$ Dans des mains expérimentées, ces appareils peuvent être utilisés avec un excellent succès chez le patient éveillé ou anesthésié. Nous devons noter que des études comparatives entre le stylet lumineux et des techniques autres que l'intubation par fibroscopie sont encore à faire.

\section{Intubation rétrograde}

L'intubation rétrograde est une technique disponible 
depuis plus de 30 ans et elle continue à demeurer intéressante. ${ }^{35}$ Cette technique implique habituellement le passage rétrograde d'un guide métallique ou d'un cathéter épidural à travers une aiguille placée dans la membrane cricothyroïdienne. Une fois ramené à travers le nez ou la bouche, ce fil peut être utilisé comme un guide pour un tube endotrachéal ou un changeur de tube, ou comme guide pour la fibroscopie. ${ }^{36}$ Même s'il y a risque de dommage aux muqueuses et aux cartilages, de perforation postérieure de l'oesophage ou de dommage aux artères. cricothyroïdiennes, le risque semble être faible puisque peu de complications ont été rapportées (ceci n'a pas été confirmé). Une des difficultés les plus fréquentes avec cette technique est l'incapacité de passer le tube endotrachéal au-delà du larynx. Elle peut être contournée par l'utilisation d'un fibroscope ou d'un stylet d'Eschmann, ou encore en attachant par un noeud coulant un cathéter épidural à l'oeil de Murphy d'un tube endotrachéal en tirant ensuite le cathéter et le tube dans le larynx à partir de l'extrémité cricothyroïdienne du cathéter ${ }^{37,38}$ On a décrit un programme de formation qui utilise des patients qui se présentent pour laryngectomie élective. ${ }^{39}$

Même si la plupart des techniques. d'intubation rétrograde impliquent la ponction de la membrane cricothyroïdienne, plusieurs avantages potentiels de l'approche crico-trachéale ont été identifiés par Abou-Madi. ${ }^{37}$ Lorsqu'il y a eu pénétration de la trachée à la suite d'une approche centrale entre le cricoïde et le premier anneau trachéal, l'aiguille utilisée n'entre pas dans le larynx et les artères cricothyroïdiennes sont épargnées. Ce niveau est habituellement suffisamment distal pour éviter l'isthme thyroïdien. L'intubation est facilitée par l'insertion du guide plus bas dans la trachée puisque le tube est placé en deça des cordes vocales avant que l'on n'ait à retirer le cathéter ou le guide métallique.

\section{La ventilation transtrachéale par jet}

Les indications, méthodes d'exécution, et les mérites des différents systèmes de ventilation transtrachéale par jet ont été revus en détails. ${ }^{40} \mathrm{La}$ ventilation transtrachéale par jet amène l'oxygénation par deux mécanismes. Premièrement, passage de la masse d'oxygène à travers la canule percutanée et ensuite entraînement d'air à partir des voies aériennes supérieures par effet Venturi. Tel que décrit par Benumof, la ventilation trachéale par jet a deux principales indications: «faciliter les interventions sur les voies aériennes », et permettre l'intubation sécuritaire de la trachée par intubation à fibroscope ou rétrograde, tout en prévenant l'incapacité à intuber et ventiler.

Benumof décrit 5 systèmes d'administration de ventilation transtrachéale par jet. Les trois meilleurs systèmes sont : l'injecteur fonctionnant par oxygène tiré d'un réservoir ou de la prise murale, l'injection d'oxygène provenant d'une source sans régulateur, l'utilisation du système de chasse d'oxygène de la machine d'anesthésie à travers une tubulure non compliante. Il y a d'autres systèmes moins efficaces mais qui peuvent quand même sauver des vies; il s'agit de l'utilisation du système à circuit fermé (avec le réservoir en place), et le branchement direct du cathéter à un réanimateur manuel. Des complications sont mentionnées et elles peuvent être divisées en 4 catégories: barotrauma, traumatisme dû au positionnement du cathéter, migration du cathéter, et les effets des gaz secs. ${ }^{41-43}$ Le barotrauma est certainement inquiétant à cause de l'utilisation d'une haute pression d'oxygène et de la résistance possible à l'expiration des gaz (problèmes notés chez $14,3 \%$ des patients dans une série) ${ }^{44}$ Les barotraumas mentionnés comprennent l'emphysème sous-cutané médiastinal et le pneumothorax. Ceci se produit plus fréquemment à la suite de tentatives non prévues de contrôle des voies aériennes. ${ }^{41}$

\section{Stylet à jet}

Bien que le système de ventilation trans-trachéale à jet puisse faciliter le contrôle d'une voie aérienne difficile, le positionnement d'un cathéter trachéal percutané peut traumatiser les tissus et la migration du dit cathéter peut amener le barotrauma. Dans certaines situations, un appareil appelé le stylet à jet peut diminuer ces risques. ${ }^{45}$ Ce stylet est un tube de polyéthylène creux de $65 \mathrm{~cm}$ disponible avec trois différents diamètres internes. Le tube peut être branché soit à un système d'anesthésie au moyen d'un adaptateur de tube endotrachéal de $15 \mathrm{~mm}$, ou à un injecteur à jet par un adaptateur mécanique type Luer Lock conique (femelle)

Le stylet à jet est placé par voie orale à l'aide de laryngoscopie directe, broncoscopie rigide, par voie rétrograde, ou dans un tube endotrachéal déjà en place. Une fois mise en place, les poumons peuvent être ventilés par n'importe lequel des systèmes de ventilation à jet disponible. ${ }^{46} \mathrm{Cet}$ appareil est un auxiliaire utile à l'extubation de patients avec pathologie ou chirurgie récente des voies aériennes supérieures. En assumant que les critères de sevrage sont respectés, le stylet à jet est positionné à travers le tube endotrachéal avant l'extubation et le tube est ensuite retiré. Si le patient nécessite une réintubation, le stylet à jet peut être utilisé pour procurer une ventilation temporaire et aussi pour servir comme un guide rigide pour le repositionnement du tube endotrachéal. Ceci réduit les inconvénients de l'extubation à risque.

\section{Cricothyrotomie}

Une bonne variété d'instruments à cricothyrotomie sont actuellement sur le marché. Ils peuvent être divisés en deux classes. Ceux qui permettent la sortie des gaz expirés à travers la lumière, et ceux avec lumière plus petite qui 
requièrent un larynx perméable pour l'expiration et l'aspiration. Des exemples d'instruments de la première catégorie comprennent le $\mathrm{Nu}$-Trake (International Medical Devices, Northridge, CA) et le Melker Emergency Cricothyrotomy Catheter Set ${ }^{\circledR}$ (Cook Critical Care, Stouffville, Ontario). Le Trans-Cricothyrotomy Device ${ }^{\circledR}$ (VBM Medizintechnik, Sulz/Neckar, Germany), un adaptateur de plastique de calibre 13 avec point d'attache est un exemple du second type. Le second type de canule est très utile pour la ventilation par jet (voir ci-dessus). Lorsqu'on a utilisé l'appareil Nu-Trake ${ }^{\circledR}$ chez des chiens, plusieurs complications ont été rapportées (hématomes sous-muqueux et traumatisme du cricoïde). De plus, les nouveaux utilisateurs ont eu plus de difficultés à placer l'appareil. ${ }^{47}$ Malgré la disponibilité de ces appareils et d'autres du même type, une enquête informelle chez des anesthésistes en pratique dans un hôpital d'enseignement a montré que seulement une minorité de ceux-ci avaient l'expérience de la cricothyrotomie.

\section{Nouveaux modèles de lames de laryngoscopes}

Le dessin des laryngoscopes peut être crucial lorsqu'il $s^{\prime}$ 'agit de résoudre des problèmes de voies aériennes. McIntyre a revu des variations anatomiques associées à l'intubation difficile (région sternale proéminente, faible distance entre les incisives, petite bouche, et larynx antérieur) et a identifié les caractéristiques importantes du dessin des lames de laryngoscope pour chaque type de problème. ${ }^{48} \mathrm{De}$ nouveaux modèles de laryngoscope continuent de surgir et ils offrent des avantages dans des circonstances spécifiques. Un tel exemple a été décrit par Bellhouse.$^{49} \mathrm{Ce}$ laryngoscope est muni d'une lame droite pliée à $45^{\circ}$ en son point central. La source lumineuse est placée à $2 \mathrm{~cm}$ du bout et un prisme peut être attaché pour les situations extrêmement difficiles (incisives supérieures très proéminentes ou larynx très antérieur). Bellhouse rapporte un taux de succès excellent dans au-delà de 3500 intubations, mais aucune étude comparative n'a été entreprise.

\section{Conclusion}

Des difficultés inattendues continuent à apparaître dans le contrôle des voies aériennes. Même si de nouveaux systèmes d'évaluation sont prometteurs, ils ont des valeurs de prédiction faibles qui limitent leur utilité. Certaines nouvelles techniques radiographiques sont utiles pour l'évaluation des patients avec pathologies ou difficultés anatomiques connues mais sont de peu de secours lorsque des problèmes inattendus surgissent. De nombreux nouveaux instruments sont disponibles pour faciliter le contrôle des problèmes des voies aériennes. L'anesthésiste doit avoir un plan qui lui permette de choisir la technique appropriée à utiliser dans une situation d'urgence. Des algorithmes publiés peuvent aider à la sélection des techniques appropriées, mais l'anesthésiste doit aussi se familiariser avec la technique particulière choisie.

\section{Références \\ (Voir page R45)}

